\title{
フィルドビア硫酸銅めっきからの析出銅結晶の特性評価
}

\author{
萩原 秀樹*，君塚 亮一**，本間 英夫***
}

\section{Characteristic Evaluations of Copper Crystal in Deposited Films by Acid Copper Plating for Via Filling}

\author{
Hideki HAGIWARA*, Ryoichi KIMIZUKA** and Hideo HONMA***
}

*関東学院大学大学院 工学研究科 ( ₹ 236-8501 神奈川県横浜市金沢区六浦東 1-50-1)

***萑原ユージライト株式会社 中央研究所（†251-0876 神奈川県藤沢市善行坂 1-1-6）

***関東学院大学 工学部（干 236-8501＼cjkstart神奈川県横浜市金沢区六浦東1-50-1）

* Graduate School of Engineering, Kanto Gakuin University (1-50-1 Mutuura-higashi, Kanazawaku, Yokohama-shi, Kanagawa 236-8501)

** Research and Development Center, EBARA-UDYLITE CO., LTD (1-6 Zengyozaka, 1-chome, Fujisawa-shi, Kanagawa 251-0876)

***Faculty of Engineering, Kanto Gakuin University (1-50-1 Mutuura-higashi, Kanazawaku, Yokohama-shi, Kanagawa 236-8501)

\begin{abstract}
Acid copper plating has been extensively applied to various fields such as decorative plating and through-hole plating. In addition to these applications, this technology has been utilized for the metalization of small electronic devices since acid copper plating was adapted to the copper damascene process. Under such new trends, the proper assessment of additives, including their controllability and accessibility for a wide variety of demands, has become an urgent issue. Using commercially available acid copper plating processes, we have evaluated these factors for via-filling and for high throwing power. We compared them in terms of changes in the crystal size and grain of the deposited copper, which are known to change with time, and we also evaluated the influence of additives on the hardness and electrical resistivity. It was confirmed that optimization in selecting and quantifying additives enables deposition of a film characteristically comparable to the acid copper plating process with high throwing power even though the process has a special deposition capability like via-filling.
\end{abstract}

Key Words: Filled Via Plating, Grain, Crystallite, X-ray Diffraction (XRD), Focused Ion Beam (FIB)

\section{1. 緒 言}

近年，硫酸銅めっきは従来までの装飾やプリント配線板 への用途のほか，パッケージ基板や半導体用途など小型電 子デバイスへの応用も盛んに進められている ${ }^{1) ~}$ その一方では多様なニーズに応じて配合されるめっき添加 剂による皮膜特性への影響が懸念される。一般に硫酸銅 めっきによって成膜された銅皮膜の結晶は，放置時間や熱 処理によって再結晶化が起こる。その結果, 結晶サイズが 大きくなることが知られている7),8)。むろん, 添加剤の種類 やめっき条件にも影響を受けるが，この結晶サイズの増大 化は結晶粒界を低減させ，その効果により皮膜の機械的物 性や体積抵抗率，エッチング特性などが改善される7),9) 11)。

今日の硫酸銅めっき開発において，活発に検討されてい るプロセスの 1 つにビアフィリング用硫酸銅めっきが挙げ られる。一般にビアフィリング用硫酸銅めっき皮膜には, ハイスロー用硫酸銅めっき皮膜と同等の機械的物性はも之 より, 電気伝導性が求められている。しかし，ビアフィリ
ング析出を行うには，ハイスロー浴にはない特殊な添加剤 を配合する必要があるため，それらの影響が懸念される。

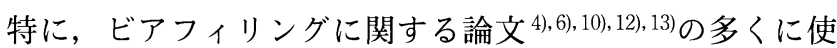
用されるヤヌスグリーン B（以下：JGB と記す）のような 染料系の levellerは，一般にハイスロー浴には添加されない 成分であるため，その銅皮膜への影響を確認する必要があ ると思われた。

そこで，本研究ではプリント配線板において高密度化に

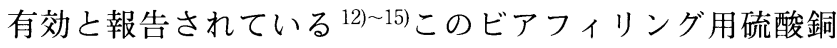
めっきによる銅皮膜について，結晶学的視点から検討を 行ったので報告する。

\section{2. 実 験}

評価には, 硫酸銅 5 水塩 $\left(\mathrm{g} / \mathrm{dm}^{3}\right)$ : 硫酸 $\left(\mathrm{g} / \mathrm{dm}^{3}\right)$ : 塩素 $\left(\mathrm{mg} / \mathrm{dm}^{3}\right)$ のみで構成された浴をVMS と称し, Table 1 に示 すような市販の 4 種のめっき浴を準備した。浴の選択には ビアフィリング用硫酸銅めっき浴として（1）染料系のフィ ルド A 浴，（2）非染料系のフィルド B浴，（3）非染料系の 
フィルドC浴, 比較として（4）非染料系のハイスローD浴 を用いた。フィルドA浴はポリエーテル系有機化合物を主 成分とする suppressor, 硫黄系有機化合物を主成分とする brightener およびアゾ系有機化合物を主成分とする leveller により構成されている。フィルドBおよびC浴はポリエー テル系有機化合物を主成分とする suppressor および硫黄系 有機化合物を主成分とする brightenerにより構成されてい る。ハイスローD浴はポリエーテル系有機化合物を主成分 とする suppressor, 硫黄系有機化合物を主成分とする brightener およびポリアミン系有機化合物を主成分とする levellerにより構成されている。

これらめっき浴の特性を評価するため，まずポテンショ スタット（北斗電工社製 HZ-3000）を用いて電流/電位曲 線を測定し，そこから 4 浴における攪找スピードと銅の析 出量の関係を検討した。この時，作用極には $5 \mathrm{~mm} \phi$ の白金 回転ディスク電極を, 対極には $3 \mathrm{~mm} \phi \times 50 \mathrm{~mm}$ 長さの銅棒 を，参照電極には銀一塩化銀電極を用いた。また，摫拌ス ピードの調整は白金回転ディスク電極の回転数で行った。 さらに, 電流/電位曲線の測定はスキャン速度を $100 \mathrm{mV} / \mathrm{s}$ としたサイクリックボルタンメトリー法で行い，そのデー 夕には波形が安定する 3 サイクル目を採用した。設定電位 $(-0.225 \mathrm{~V} \sim 1.575 \mathrm{~V})$ あたりの銅の析出量 $(\mathrm{mC})$ は, 電流/電 位曲線における銅の剥離曲線部分を付属の解析ソフトを用 い積分計算して得た。

今回の評価で用いたテストピースには，ブラインドビア

Table 1. Compositions of Virgin Make-up Solutions $\left(\mathrm{VMS}=\mathrm{CuSO}_{4} \cdot 5 \mathrm{H}_{2} \mathrm{O}\left(\mathrm{g} / \mathrm{dm}^{3}\right): \mathrm{H}_{2} \mathrm{SO}_{4}\left(\mathrm{~g} / \mathrm{dm}^{3}\right): \mathrm{Cl}^{-}\right.$ $\left.\left(\mathrm{mg} / \mathrm{dm}^{3}\right)\right)$ and Baths A to D

\begin{tabular}{c|c|c}
\hline Type & Composition & \\
\hline VMS 1 & & $200: 50: 60$ \\
VMS 2 & $\mathrm{CuSO}_{4} \cdot 5 \mathrm{H}_{2} \mathrm{O}\left(\mathrm{g} / \mathrm{dm}^{3}\right): \mathrm{H}_{2} \mathrm{SO}_{4}\left(\mathrm{~g} / \mathrm{dm}^{3}\right): \mathrm{Cl}^{-}\left(\mathrm{mg} / \mathrm{dm}^{3}\right)$ & $150: 100: 30$ \\
VMS 3 & & $75: 180: 60$ \\
\hline Bath A & VMS 1 with additive A & \\
\hline Bath B & VMS 1 with additive B & \\
\hline Bath C & VMS 2 with additive C & \\
\hline Bath D & VMS 3 with additive D & \\
\hline
\end{tabular}

ホール（以下：ビアホールと記す）径 100 および $140 \mu \mathrm{m} \phi$, 深さ $65 \mu \mathrm{m}$ の設けられているパネル基板と, ビアホール径 $70 \mu \mathrm{m} \phi$, ランド径 $120 \mu \mathrm{m} \phi$, 深さ $45 \mu \mathrm{m}$ の設けられている パターン基板の 2 種を用いた。パネル基板ではビアホール への析出性を確認するため, $2 \mathrm{~A} / \mathrm{dm}^{2} て ゙ 20 \mu \mathrm{m}$ のめっき後に ビアホールの断面観察を行った。さらに, めっき後の経時 変化に伴う結晶子サイズの変化をX-ray diffraction（島津製 作所社製 XRD-6100以下：XRD と記す）測定から求めた。 また皮膜の硬度測定を微小硬度計（AKASHI社製 MVKG3）を用い，体積抵抗率を低抵抗率計（三菱化学社製 ロレスターEP）を用いて測定した。

パターン基板では代表してフィルド $\mathrm{A} ， \mathrm{~B}$ およびC浴を 用い $2 \mathrm{~A} / \mathrm{dm}^{2} て ゙ 15 \mu \mathrm{m}$ めっきした後， 2 週間室温で放置した 後に Focused Ion Beam（エスアイアイ・ナノテクノロジー ズ社製 SMI3050SE以下：FIB と記す）を用い，ビアホール 断面部の Scanning Ion Microscopy（以下：SIM と記す）像 の観察を行い結晶の見かけ上の粒径を求めた ${ }^{16), 17) 。 さ ら に, ~}$ この粒径とXRD測定によって算出された結晶子サイズとの 大きさを比較した。

\section{3. 結果と考察}

\section{1 電気化学測定によるめっき浴の検討}

準備した 4 種のめっき浴を用いて電流/電位曲線を測定 し，そこから攪拌スピードと銅の析出量の関係を検討した。 その結果をFig. 1に示す。この結果では，添加剤の入らな いVMS 1 3において，攪汼スピードに応じて銅の析出量 が増加していた。中でも銅濃度の最も低いVMS 3 の攪找依

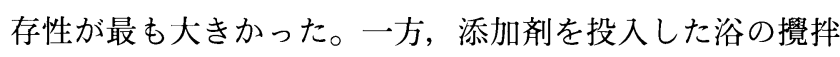
スピードである 100 2500 rpm を比較すると, 右下がりの傾 きが大きい浴ほどビアホール底からの優先析出が期待でき ると考えられることから ${ }^{18)}$ ，フィリング特性はフィルド A 浴>フィルドB浴>フィルドC浴>ハイスローD浴の順にな る可能性が高いと推測された。このメカニズムは, めっき 中のビアホール近傍に置き換えて考えられている。すなわ ち, 攪拌の強い箇所がビアホールの外側を模擬し, 弱い箇 所がビアホールの内部を模擬している。このため, 電気化 学測定において攪拌スピードの早い時より遅い時の銅の析
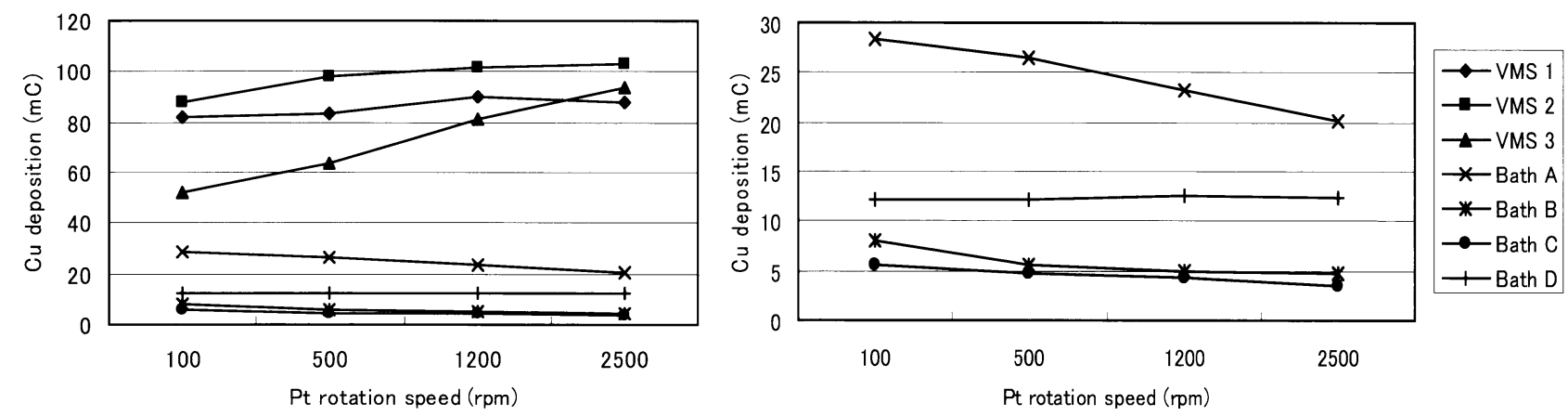

Fig. 1 Dependence of copper deposition rate on rotation speed of the Rotation Disc Electrode (RDE) (working electrode) for VMS's 1 to 3 and Baths $A$ to $D$ (Left: $\sim 120 \mathrm{mC}$; Right: Close-up of the graph to the left up to $30 \mathrm{mC}$ ) 


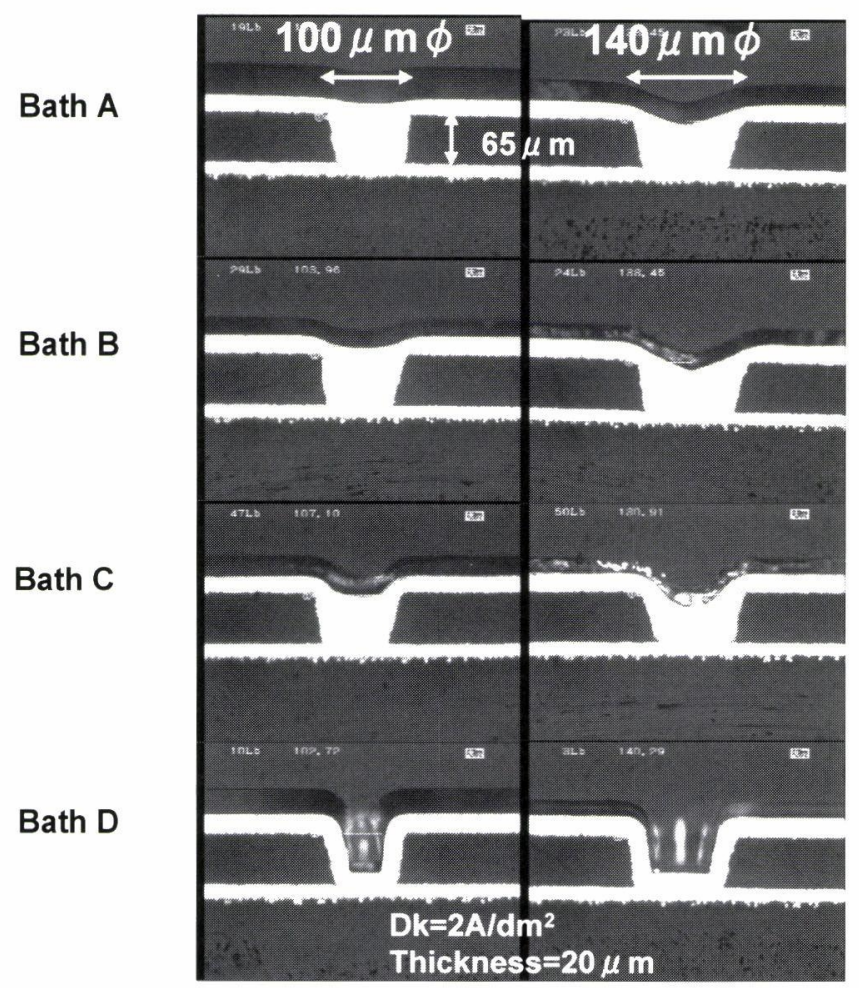

Fig. 2 Cross-sectional views of via holes plated in Baths A to D

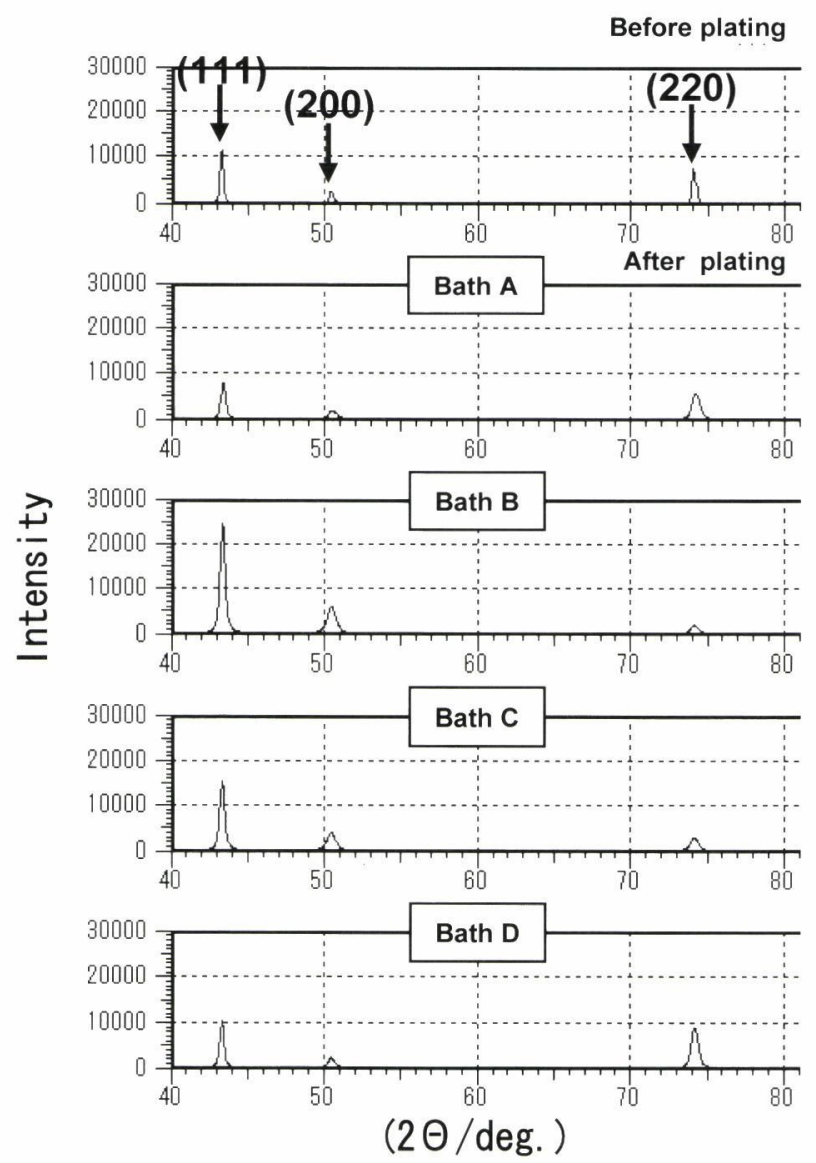

Fig. 3 XRD peak profiles of the $20 \mu$ m-thick Cu film deposited by electro $\mathrm{Cu}$ on the electroless $\mathrm{Cu}$ substrate, as soon as plating
出量が多いほど，高いフィリング特性が示されると考えら れた。

\section{2 断面観察によるフィリング特性の評価}

そこで，実際にビアホールの設けられているパネル基板 に 4 種のめっき浴を用いてめっき加工を行った。その結果 を Fig. 2 に示す。ここではビアフィリング用硫酸銅めっき においてボトムアップ析出を，ハイスロー用硫酸銅めっき においてはコンフォーマル析出の確認ができる。特に, ビ アフィリング用硫酸銅めっきでは, 前述において予想通り のフィリング特性となっていた。すなわち，フィルドA浴〉 フィルド $\mathrm{B}$ 浴>フィルドC浴>ハイスローD浴の順となっ ていることを確認した。この傾向は, 電気化学測定により フィリング特性を判断できる可能性を示唆するものである と考えられる。

\section{$3.3 \mathrm{XRD}$ 測定}

\subsection{1 配向性の評価}

各めっき浴による銅皮膜の XRD パターンをFig. 3 および Fig. 4 に示す。Fig. 3 は, めっき後 5 分以内に, Fig. 4 は2 週 間経過後に測定した結果である。これより，フィルドA浴 は他の 3 浴に比へ、経過時間に伴う結晶度の増加が少ない ことが確認される。さらに，銅のパウダーディフラクショ

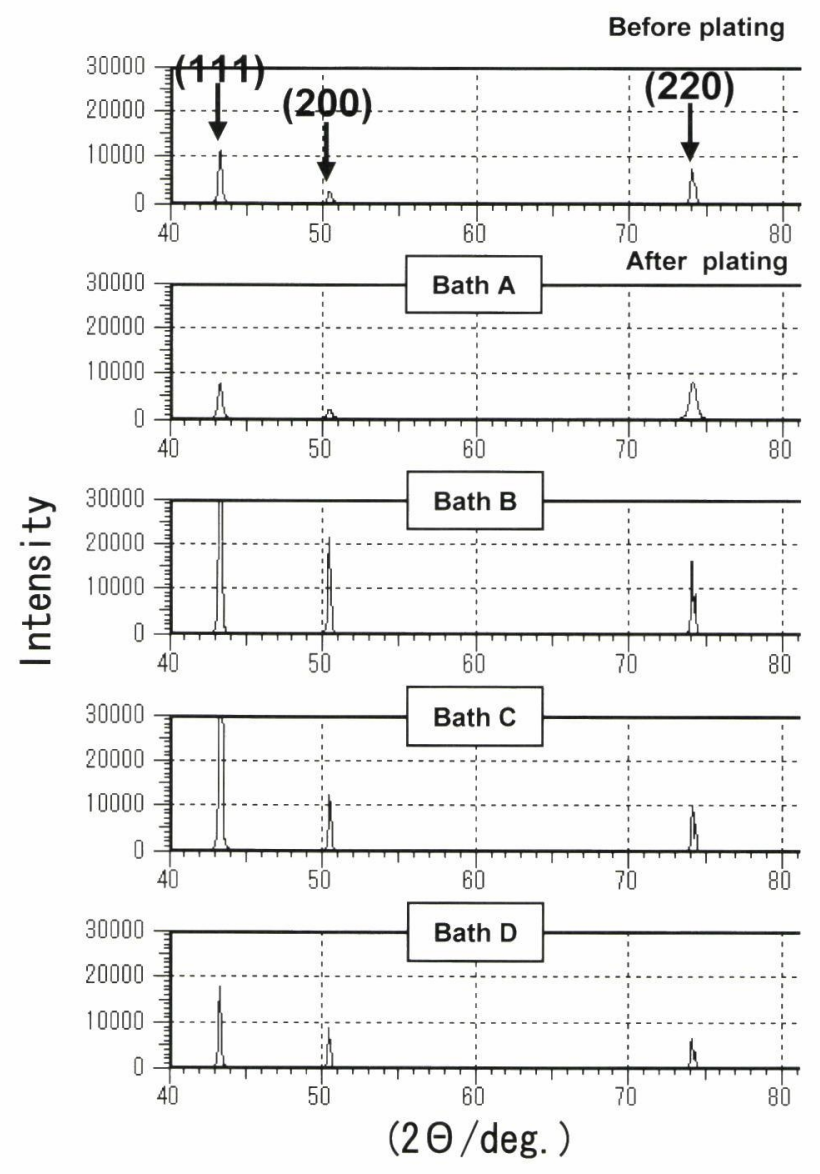

Fig. 4 XRD peak profiles of the $20 \mu$ m-thick Cu film deposited by electro $\mathrm{Cu}$ on the electroless $\mathrm{Cu}$ substrate, and aged at room temperature for 2 weeks 
ン $\{(111)$ の強度比を 100 とした際，(200) で同 46, (220) で 同 20$\}$ と比較して (220) に優先配向を示していた。一方, フィルド BおよびC浴は経過時間に伴う結晶度の増加が多 く，配向性もめっき直後より (111) に優先配向を示してい た。比較として用いたハイスローD浴も，めっき直後には (220) に優先配向を示していたものの，2週間経過時点では (111) に優先配向を示していた。このことから, 今回用いた 4 種のめっき浴のうち, フィルド A 浴だけは結晶の配向性 に異なった性質を持つ可能性が考えられた。

\section{3 .2 結晶子サイズの測定}

同時に，前項3.3.1におけるXRD 測定結果から，ブラッ

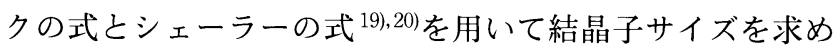
た。その結果をFig. 5 に示す。いずれの浴も，めっき直後 は素地である無電解銅めっき皮膜の結晶子サイズよりも小 さくなっていた。しかし，2週間後ではフィルドB， C浴お よびハイスローD浴において素地の無電解銅めっき皮膜よ り結晶子サイズが大きく成長していた一方で，フィルド $\mathrm{A}$

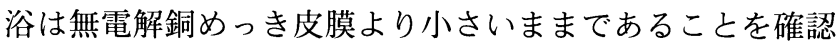
した。今回用いためっき浴の中で，アゾ系の levellerが用い られていたのはフィルドA浴だけである。この leveller が再 結晶化を妨げていた可能性が示唆された。

\section{4 硬度の測定}

次に皮膜の結晶特性と硬度の関係を確認するため，めっ

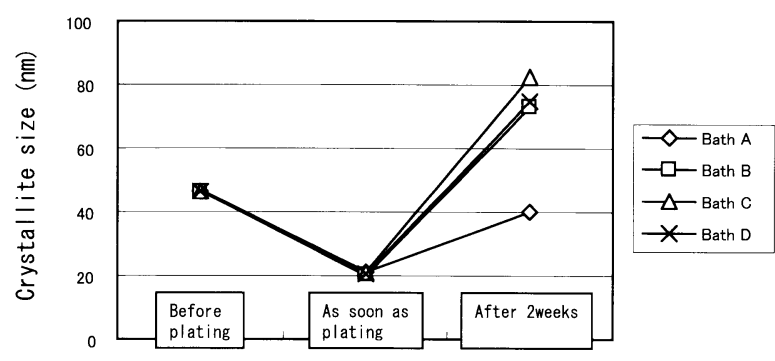

Fig. 5 Change in crystallite size for Baths $A$ to $D$, aged at room temperature
き直後から 2 週間経過するまでの皮膜の硬度を測定した。 その結果をFig. 6 に示す。いずれの浴もめっき直後は $180 \mathrm{Hv}$ 以上の高い硬度を示していたが, 24 時間後にはフィルド A 浴以外の 3 浴において $120 \mathrm{Hv}$ までの低下が確認された。し かし，フィルド A 浴は 2 週間経過しても他の 3 浴ほど硬度 は低下しなかった。この原因もアゾ系の leveller が関与して いると考えられた。

\section{5 体積抵抗率の測定}

同様に体積抵抗率の測定結果をFig. 7 に示す。この結果 では, いずれも電気めっきの前に $2.98 \mu \Omega \cdot \mathrm{cm}$ であった無電 解銅めっき皮膜の体積抵抗率が, 電気めっき直後において $2.2 \mu \Omega \cdot \mathrm{cm}$ 付近まで低下し, 2 週間経過後には $2.0 \mu \Omega \cdot \mathrm{cm}$ 以 下にまで低下していることを確認した。しかし，本項にお いても 2 週間経過後のフィルド A 浴の体積抵抗率は, 他の 3浴ほど低下しなかった。ここにおいても，アゾ系の leveller が関与する皮膜特性への影響が示唆された。一方，同 じフィルド浴であっても BやC浴ではハイスローD浴と同 等の体積抵抗率を示していることから, 添加剤の選択によ り皮膜特性は影響を受けることが確認された。

\subsection{FIBによるSIM像観察}

フィルド $\mathrm{A}, \mathrm{B}$ および $\mathrm{C}$ 浴を用いて，めっきしたパター ン基板に設けられているビアホール周辺部の皮膜を FIBに

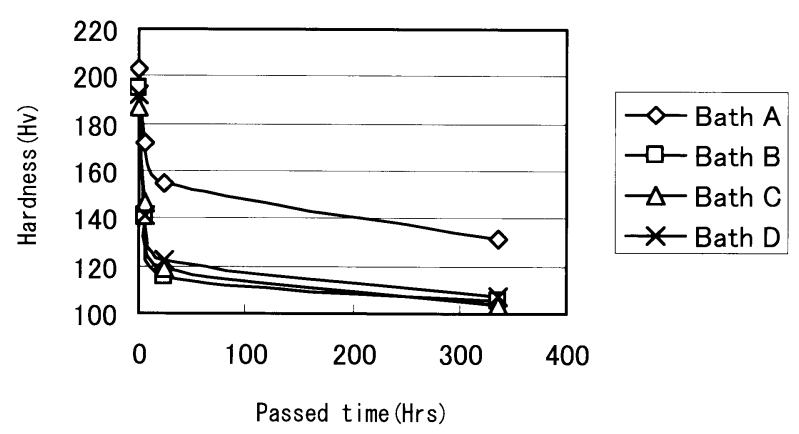

Fig. 6 Change in vickers hardness for Baths $A$ to $D$, aged at room temperature

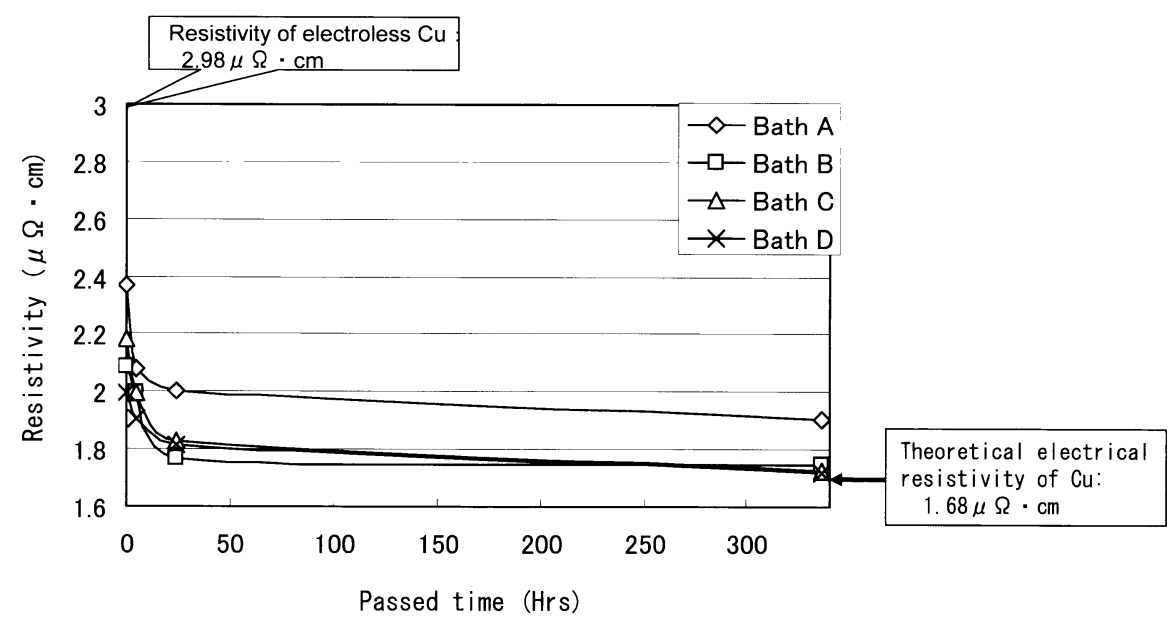

Fig. 7 Change in electrical resistivity of the $20 \mu$ m-thick $\mathrm{Cu}$ film deposited by electro $\mathrm{Cu}$ on electroless $\mathrm{Cu}$ substrate in Baths $A$ to $D$, and aged at room temperature 


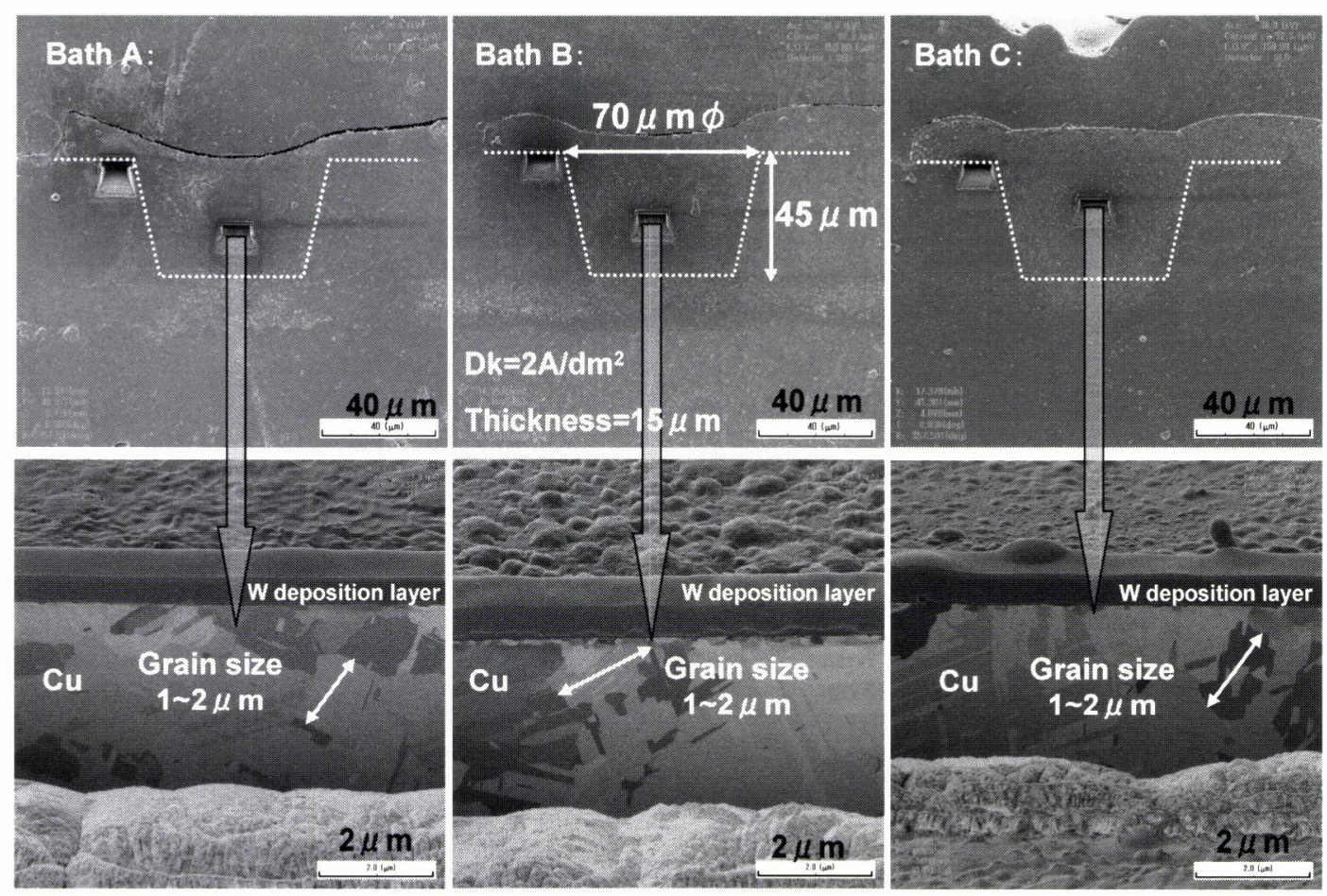

Fig. 8 Cross-sectional SIM images of Cu films deposited in Baths A to C, and aged at room temperature for 2 weeks

よって削りだし, SIM像によって観察した結果をFig. 8に 示す。これらの像からは前述までの結果と一転し, いずれ の浴に扔いても銅の見かけ上の結晶粆径は $1 \sim 2 \mu \mathrm{m}$ 程度で あることがわかる。これにより,フィルドA浴による皮膜へ の影響は，粒径サイズへ与えるむのではないと考えられた。 一方, 3.3.2 項の Fig. 5 において求められた A, BおよびC

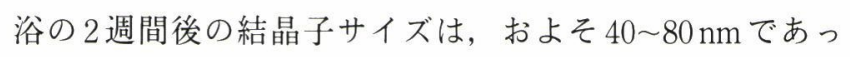
た。この結晶子サイズと粒径の間には約20 30 倍ものディ メンションの差があるが, これは単結晶とみなせる結晶子 之, それらが集って構成される粒径の違いによるものと考 えられた ${ }^{20)}$ これららの模式図をFig. 9に示す。めっき皮膜 を含屯金属の結晶は, 結晶子と粒径によって構成されてお り, これらの大小や多少によって皮膜特性は大きく異なる と思われる。すなわち, フィルドA浴による皮膜の特性は, 結晶子サイズに依存していた可能性が高く, この結晶子サ イズに影響を与える要因がアゾ系の levellerであったと考元 られた。

これまでの報告から，一般にめっき皮膜の硬さは，その 結晶粒子の大きさに起因していることが知られている ${ }^{21}$ 。 これは, 結晶粒径が微細になると結晶粒界が増加し, それ はすべり面を固定することから結晶は動けなくなり，その 結果，金属は硬くなるというものである。これに基づけば, フィルドA浴のSIM像による見かけ上の粒径は他のフィル ドBおよびC浴より小さいはずである。しかし，本検討で はそのような傾向が確認できるほど大きな差がなかったこ とから，フィルドA浴で用いられているアゾ系の leveller は, 結晶粒径の増大化を抑制するものではなく, 結晶子サ

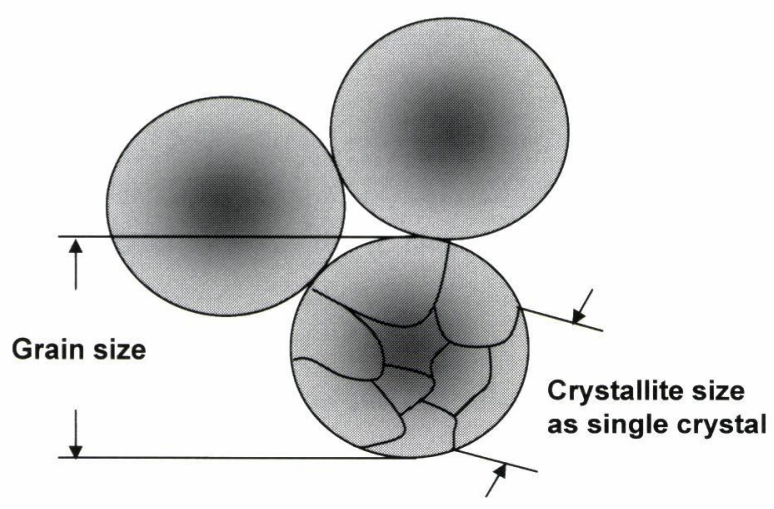

Fig. 9 Relationship between grain size and crystallite size

イズの増大化を抑制するものと考えられた。

\section{4. 結 言}

本研究では, 市販のハイスロー用硫酸銅めっき浴を比較 として，3種のビアフィリング用硫酸銅めっき浴の皮膜特 性を評価した。その結果, フィルドB拈よびC浴のように ビアフィリングのような特殊な析出を可能とする添加剤で あっても, 種類や添加量の最適化がなされればハイスロー 浴と同等の皮膜特性を有することを確認した。一方, 同じ フィルド浴であっても，A浴は他の浴と異なった皮膜特性 を示した。この原因には, 他の3浴に用いられていないア ゾ系の leveller が起因していると考えられた。一般にJGBに 代表されるアゾ系の leveller は, 吸着力が強く電析の際に銅 の皮膜中へ取り込まれたり ${ }^{10)}$, マイクロボイドの原因とな

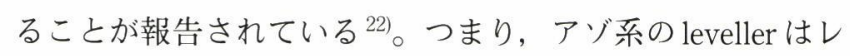


ベリングに帰属するフィリング効果が大きい反面，銅皮膜 への影響も大きい特性を兼ね備えていると考えられた。

ただし，本検討はめっき後に一切の熱処理を行わず，単 純に添加剂による銅皮膜のセルフアニールへの影響を観察 してきたものである。実際の PCB デバイス製造工程では, めっき後に $100 \sim 200^{\circ} \mathrm{C}$ の, LSI デバイス製造工程では, めっき後に $100 \sim 400^{\circ} \mathrm{C}$ の熱処理を行うことで銅皮膜へ吸蔵 した水素や共析した添加剤の除去, およびマイクロボイド の低減や結晶化の促進などによって後工程に影響が残らな いような工程が組まれている7),23) 25)。そのため, アゾ系の leveller をはじめとした吸着の強い添加剤を用いても, 適し た工程管理により高いパフォーマンスを有する銅皮膜が得 られていると考えられる。

\section{謝 辞}

本研究は文部科学省ハイテク・リサーチ・センター整備 事業（平成 17 年度〜平成 22 年度）による私学助成を得て 行われたものである。

（2005.8.12-受理）

\section{文献}

1）若林信一：“半導体実装とめっき技術”，めっき技術，Vol. 13, No. 12, pp. 7-15, 2000

2) 宇都宮久修：“半導体パッケージの将来展望”, エレクトロ ニクス実装技術，Vol. 16，No. 4, pp. 12-19, 2000

3) M. Tsujimura, K. Mishima, J. Kunisawa, N. Makino, T. Matsuda, H. Kaneko and K. Okumura: "A Novel Compact ECD Tool for ULSI Cu Metallization”, The 9th International Symposium on Semiconductor Manufacturing, Tokyo, pp. 106-109, 2000

4) 高田祐一, 小山田仁子, 三浦修平, 本間英夫 : “電気銅 めっきによるULSI 配線形成”，エレクトロニクス実装学会 誌, Vol. 4, No. 3, pp. 219-224, 2001

5) 小山田仁子, 三浦修平, 本間英夫：“ULSI配線形成におけ るステップ式電解波形制御の有効性”，エレクトロニクス実 装学会誌, Vol. 5, No. 1, pp. 79-81, 2002

6) 根岸芳典, 長谷川 円, 中西卓也, 逢坂哲爾 : “ULSI 配線 用ダマシン銅めっきにおける添加剂が析出に及ぼす影響”, 表面技術協会第 110 回講演大会要旨集, 14A-11, p. 45, 2004

7）上野和良：“銅微細配線技術の現状と課題”，表面技術協会 第 101 回講演大会要旨集，21D-依頼講演 (4), pp. 306-309, 2000

8) M. Moriyama, K. Matsunaga, T. Morita, S. Tsukimoto and M. Murakami: "The Effect of Strain Distribution on Abnormal Grain Growth in $\mathrm{Cu}$ Thin Films”, Materials Transactions, Vol.

45, No. 10, pp. 3033-3038, 2004
9) T. Nakagawa: "The Relationship between Self-annealing of Plated Copper and Copper Surface Treatment”, Circuit World, Vol. 29, No. 3, pp. 22-26, 2003

10) H. Hagiwara, H. Honma and R. Kimizuka: "Characterization of Acid Copper Plating Solution for Via-Filling”, ECWC10 Proceeding, pp. S37-1-1-S37-1-7, 2005

11) K. Ishii: "New Method of PWB Acid Copper Plating Bath Control by Vickers Hardness Test" THE 3rd ASIAN SURFACE FINISHING FORUM, SEOUL, pp. 97-104, 1989

12）小林 健, 川崎淳一, 三原邦昭, 山下嗣人, 本間英夫 : “電気銅めっきによるビアフィリング性に及ぼす浴組成の検 討”，エレクトロニクス実装学会誌, Vol. 3, No. 4, pp. 324-329, 2000

13）小山田仁子，西中山 宏，渡邊新吾，本間英夫：“電気銅 めっきにおける添加剤のビアフィリング能の電析時間依存 性”, エレクトロニクス実装学会誌, Vol. 7, No. 3, pp. 261-265, 2004

14) W. Dow and H. Huang: "Roles of Chloride Ion in Microvia Filling by Copper Electrodeposition”, J. of The Electrochemical Society, Vol. 152, No. 2, pp. C67-C76, 2005

15）神田 武：“ビルドアッププリント配線板「スタック MVIA」”，電子材料，Vol. 40, No. 10, pp. 120-124, 2001

16）鈴木俊明, 遠藤徳明, 柴田昌照, 釜崎清治, 市八川竹男 : “ナノテクノロジーをサポートするSIM像の応用”，表面技 術, Vol. 53, No. 12, pp. 839-842, 2002

17) 平坂雅男, 朝倉健太郎：“電子顕微鏡研究者のためのFIB · イオンミリング技法 Q\&A”，アグネ承風社，p. 37, 2002

18）山川統広, 田中善之助, 近藤和夫 : “ビア底での穴埋め添 加剤のメカニズム”, MES2000（第10回マイクロエレクト ロニクスシンポジウム) 要旨集, pp. 51-54, 2000

19）カリティー著, 松村源太郎訳 : “新版 $X$ 線回折要論”, ア グネ社, pp. 77-94, 1961

20）早稲田嘉夫, 松原英一郎：“X線構造解析”, 内田老鶴圃 社, pp. 73-126, 1998

21）尾形幹夫：“やさしいメッキ理論入門”，実務表面技術， Vol. 75, No. 2, p. 45, 1975

22）縄舟秀美：“銅微細配線技術の課題”，表面技術協会第 101 回講演大会要旨集，21D-依頼講演(5), pp. 310-313, 2000

23）日本プレーティング協会：“現場技術者のための実用めっき (II)”橹書店, p. 172-180, 1982

24) 前田和夫 : “はじめての半導体プロセス”, 工業調査会, pp. $82-86,2000$

25）萩原秀樹，小林 健，君塚亮一：“エレクトロニクス分野 への硫酸銅めっき技術”，表面技術，Vol. 52, No. 1, pp. $50-51,2001$ 